\title{
ANALISIS PEMAKSAAN MENIKAH MENURUT HUKUM ISLAM
}

\author{
Dra. Yusriana, SH,M.Hum \\ Universitas Amir Hamzah \\ yusriana321@gmail.com
}

\begin{abstract}
Abstrak
Fungsi perkawinan adalah merupakan suatu nilai hidup untuk dapat meneruskan keturunan, mempertahankan silsilah dan kedudukan keluarga yang bersangkutan.Disamping itu ada kalanya suatu perkawinan merupakan suatu sarana untuk memperbaiki hubungan kekerabatan yang telah jauh atau retak.Ia merupakan sarana untuk pendekatan dan perdamaian antara kerabat dan begitu pula dengan perkawinan itu bersangkut paut dengan masalah kedudukan, harta kekayaan dan masalah kewarisan. Upaya untuk melakukan regenerasi dalam Islam telah diatur dengan tata cara yang sedemikian rupa supaya ada perbedaan dengan makhluk ciptaan Allah yang lain, dimana dikenal dengan fiqih munakahat. Makna ikatan ini tidak hanya seorang lakilaki dan perempuan untuk menghalalkan persetubuhan.Tapi Allah menyebutkan pernikahan itu adalah janji yang erat, yaitu perjanjian antara suami dan istri untuk hidup bersama. Sehingga bila mereka dipisahkan oleh kematian maka akan dipersatukan lagi diakhirat asal tetap melaksanakan perintah-perintah Allah. Dalam sejarah terbentuknya perjalanan masyarakat dimulai dari hubungan personal antara manusia satu dengan yang lainnya. Dalam rangka pemenuhan kebutuhan, antara lain untuk memperoleh keturunan, maka timbullah hubungan antar laki-laki dan perempuan yang sudah menjadi kodrat alam bahwa dua orang manusia dengan dua jenis kelamin yang berbeda, seorang laki-laki dan perempuan ada daya tarik satu sama lain untuk hidup bersama.
\end{abstract}

\section{Kata kunci : Pemaksaan Menikah, Hukum Islam}

\section{PENDAHULUAN}

Perkawinan itu haruslah sukarela. Selanjutnya perkawinan dimaksudkan bersifat internal dan bersifat monogami.Agama mengajarkan kepada umat manusia untuk memilih jodoh dengan empat kriteria yaitu karena cantiknya, karena keturunannya, hartanya dan karena agamanya (akhlak), yang lebih utama dari 
keempat kriteria itu adalah karena agamanya.Dengan konsep yang diterapkan oleh Islam ini memberi gambaran bahwa seorang anak memiliki hak untuk menentukan pilihan pasangan untuk menjadi pendampingnya dalam rumah tangga.Para wali itu sendiri tidak boleh mengawinkan anak secara paksa. Kawin paksa atau Ijbar adalah suatu tindakan untuk melakukan sesuatu atas dasar tanggungjawab. Namun selama ini dan merupakan pandangan umum masih ada praktik masyarakat bahawaIjbar dari hak orang tua untuk menikahkan anak perempuannya atau dikenal dengan kawin paksa. Artinya hak Ijbar dipahami banyak orang sebagai hal memaksakan suatu perkawinan oleh orang lain yang dalam hal ini adalah ayahnya yang disebut wali mujbir. Kawin paksa juga merupakan suatu penyimpangan dan kekerasan terhadap kedua calon mempelai, apalagi kalau kawin paksa dilakukan terhadap anak di bawah umur.Efek tindakan ini dapat lebih parah ketimbang kekerasan fisik.Walaupun terkadang kawin paksa berakhir dengan bahagia dan sakinah berupa kebahagian rumah tangga, namun tidak sedikit yang berimbas pada ketidak harmonisan atau perceraian.Hal tersebut karena akibat ikatan perkawinan yang tidak dilandasi cinta kasih, namun berangkat dari keterpaksaan semata.Selain itu kawin paksa juga membawa dampak yang negatif terhadap perempuan seperti dalam aspek psikologis membuat perempuan tertekan, nervous, apatis dan penyesalan diri.Kemudian, kawin paksa juga sangat potensial menimbulkan kekerasan dalam rumah tangga dan berujung pada perceraian. Pada hakikatnya, akad nikah adalah pertalian yang teguh dan kuat dalam hidup dan kehidupan manusia, bukan saja antara suami isteri dan keturunannya, melainkan antara dua keluarga.Dari baiknya pergaulan antara si isteri dengan suaminya, kasih-mengasihi, berpindahlah kebaikan itu kepada semua keluarga kedua belah pihak sehingga mereka menjadi integral dalam segala urusan sesamanya dalam menjalankan kebaikan dan mecegah segala kejahatan. 


\section{KAJIAN PUSTAKA}

Hukum Islam kawin paksa dikenal dengan ijbar. Ijbar terjadi karena adanya kekuasaan wali yang disebut dengan hak ijbar. Hak tersebut dimiliki oleh ayah dan kakek terus keatas. Di dalam kawin paksa (ijbar) ada beberapa syarat yang harus dipenuhi disamping memenuhi rukun nikah sebagaimana pernikahan biasa. Kawin paksa atau Ijbar adalah suatu tindakan untuk melakukan sesuatu atas dasar tanggungjawab. Namun selama ini dan merupakan pandangan umum masih ada dalam praktik masyarakat bahwa ijbar dari hak orangtua untuk menikahkan anak perempuannya atau dikenal dengan kawin paksa. Artinya hak ijbar dipahami banyak orang sebagai hal memaksakan suatu perkawinan oleh orang lain yang dalam hal ini adalah ayahnya yang disebut wali mujbir. Wali dalam perwalian diartikan dengan keberadaan seseorang yang menjadikan akad nikah an tidak sah tanpanya. Sedangkan menurut Hukum Islam kawin paksa dikenal dengan ijbar. Ijbar terjadi karena adanya kekuasaan wali yang disebut dengan hak ijbar. Hak tersebut dimiliki oleh ayah dan kakek terus keatas. Di dalam kawin paksa (ijbar) ada beberapa syarat yang harus dipenuhi disamping memenuhi rukun nikah sebagaimana pernikahan biasa. Ijbar digunakan madzhab Syafi'I, syarat kawin paksa (ijbar) menurut Imam Syafi'I yaitu: mempelai laki-laki harus sepadan dengan mempelai perempuan, maskawin harus di bayar secara tunai oleh mempelai laki-laki, antara mempelai perempuan dan memepelai laki-laki.

\section{DISCUSSION}

\section{Kawin Paksa Dalam Hukum Islam dan Hukum Positif}

Di dalam ajaran agama Islam terdapat hukum atau aturan perundang-undangan yang harus dipatuhi oleh setiap umat, adapun hukum atau aturan-aturan yang dimksud dalam pembahasan ini yaitu yang bersumber dari al-Qur'an, Hadist dan Ijma' ulama. Indonesia yang dianggap sebagai salah satu negara muslim telah mengaktualisasikan beberapa konsep perkawinan dalam literatur fiqh kedalam legislasi nasional yang disebut juga hukum positif yang berupa undang-undang 
dan peraturan lainnya.46Adapun peraturan yang dimaksud dalam pembahasan ini yaitu Undang-Undang tentang perkawinan dan Kompilasi Hukum Islam (KHI). Persoalan wali dan persetujuan mempelai perempuan merupakan unsur penting dalam sebuah keabsahan pernikahan.untuk menghubungkan dengan konteks dan zaman dewasa ini, akan dipaparkan persoalan ijbar dengan wali dan kebebasan perempuan dalam perkawinan di dalam perundang-undangan.

\section{Analisa Hukum Islam Terhadap Kawin Paksa}

Perkawinan merupakan suatu yang sakral dilakukan oleh laki-laki dan perempuan dalam membangun suatu keluarga yang harmonis, abadi, sakinah, mawaddah dan rahmah serta menghalalkan hubungan suami istri guna untuk meneruskan keturunan, sehingga dalam perkawinan tersebut harus didasari rasa cinta dan kerelaan kedua belah pihak (calon suami istri). Karena rasa cinta dan kerelaan mereka (calon suami istri) sangat berpengaruh terhadap kelangsungan rumah tangga yang akan mereka jalani. Dengan melihat kepada hakikat perkawinan itu merupakan akad yang membolehkan laki-laki dan perempuan melakukan sesuatu yang sebelumnya tidak dibolehkan, maka dapat dikatakan bahwa hukum asal dari perkawinan itu adalah mubah dan boleh.Dengan demikian, dapat dikatakan bahwa melangsungkan akad perkawinan disuruh oleh agama, ketika akad perkawinan telah berlangsung, maka pergaulan laki-laki dengan perempuan menjadi mubah. Oleh karena itu, meskipun perkawinan itu asalnya adalah mubah, namun dapat berubah menurut ahkamul khamsah (hukum yang lima) menurut perubahan keadaan

\section{KESIMPULAN}

\section{Kesimpulan}

1. Kawin paksa dibenarkan dalam hukum Islam karena untuk kemaslahatan dan untuk menjaga keturunan atau Hifdzu Nasab dalam menghindari perbuatan zina. 
2. Kawin paksa faktor hamil di luar nikah dibenarkan oleh Hukum Islam karena untuk menjaga kemashlahatan yaitu menjaga status anak yang di kandungnya. Maka, hal ini sesuai dengan syari'at agama.

3. Kawin paksa karena faktor perjodohan tidak dibenarkan oleh hukum Islam karena di dalam Islam perjodohan itu merebut hak anak dalam menentukan jodohnya. Namun apabila ada persetujuan dari kedua pihak dan sudah memenuhi syaratsyarat yng ditentukan maka perjodohan diperbolehkan.

\section{Saran}

1. Hendaknya masyarakat mematuhi peraturan yang telah ada dan disepakati bersama dan masyarakata juga harus mengetahui akan hakikat perkawinan atau hukum positif.

2. Seharusnya orangtua lebih memperhatikan dan mengawasi anaknya dalam bergaul. Orang tua juga harus selektif dalam memilihkan jodoh untuk anaknya dan orang tua jugaharus memberikan ruang atas hak dan pilihan anak, sebab pilihan orang tua juga belum tentu baik untuk anak.

3. Hendaknya perangkat desa, masyarakat, pemuda karangtaruna membuat peraturan tertulis agar memiliki kekuatan hukum tetap dan sanksi yang diberikan kepada pelanggarnya.

\section{REFERENCES}

Al-Shabbagh. Mahmud. Tuntutan Keluarga Bahagia Menurut Islam.Bandung: PT. Remaja Rosda Karya. 1991

Abdush-Shomad. Muhiyyidin dkk.Umat Bertanya Ulama Menjawab Seputar Karir, Pernikahan dan Kelurga.Jakarta: Rahima. 2008.

Aminuddin dan Abidin. Slamet.Fiqih Munakahat 1. Bandung: CV Pustaka Setia. 1999.

As-Sayyid. Bin.Kamal. Abu Malik. Shahih Fikih Lengkap Berdasarkan DalilDalil dan Penjelasan Para Imam Yang Masyur. Jakarta: Pustaka Azzam. 2007. 
al-Asqalani. Hajar. Ibnu. Fath al-Bahri, cet . ix. Mathba'ah as-Salafiyyah. t.t. AlJaziri. Abdurrahman.Fiqih ala Madzab Arba'ah.Dalam Miftahul Huda, Nikah Paksa, Ijbar Nikah dan Hak-Hak Reproduksi Perempuan. Yogyakarta: STAIN Ponorogo Press, 2009.

Bakri. Nazar. Sidi.Kunci Keutuhan Rumah Tangga (Keluarga Yang Sakinah). Jakarta: CV. Pedoman Ilmu Jaya.1993.

Djalil. Basiq, Tebaran Pemikiran Keislaman Di Tanah Gayo.Jakarta: Qoibun Salim. 2007.

Iskandar. Metodologi Penelitian dan Sosial (Kuantitatif dan Kualitatif). Jakarta: GP. Press, 2009. 